\title{
IMPROVING TRADITIONAL MARKET CUSTOMER LOYALTY (REVISIT CONSUMER BEHAVIOUR MODEL USING CONSUMER EXPERIENCE)
}

\author{
Risca Fitri Ayuni, Ananda Sabil Hussein, and Radhita Hapsari \\ Universitas of Brawijaya
}

\begin{abstract}
The main purpose of this study is to explore any dimension from traditional market consumer's experiences that could affect their behaviour. The variables included in this study are experience quality, perceived value, visitor's satisfaction, and customer loyalty. This study divided into two phases: exploring any indicators that construct the experience quality of traditional market's customer using Exploratory Factor Analysis, and analysing the relationship between the variables on the model. In the first phase, the data was collected by doing a Focus Discussion Group that consist of six to nine traditional market's customers. The data for the second phase was collected by questionnaire on 250 traditional market's customer. This study found there are seven indicators that could construct the experience quality of traditional market's customer, however the experience quality is found to have no significant effect toward customer loyalty. In addition perceived value and visitor's satisfaction is proved to have significant effect toward customer loyalty, thus these two variables could fully mediate the relationship between experience quality and customer loyalty.
\end{abstract}

Keywords: Experience Quality, Perceived Value, Visitor's Satisfaction, Customer's Loyalty

\section{RESEARCH BACKGROUND}


Traditional market usually found in development country such as Malaysia, Thailand, Philippines and Indonesia. What makes traditional market different from department store is the government has a role to make the regulation and monitoring the management of the market, as in some country such as Indonesia traditional market has a big impact to the country's economy (Ars, 2015). Indonesia has at least 13.450 traditional markets all over the country (Kuncahyo, 2016). The market can be found in every city and villages with around $12.5 \%$ or 30 million people of Indonesia are traditional market's retailers (Kompas.com, 21/12/2016). As the word "traditional", the facilities of the market is fall short from the facilities of department store, which affect the declining number of visitors from younger generation (Kuncahwati, 2016). A survey conducted by AC Nielsen shown that department store have an impressive $31 \%$ increasing in visitors every year, meanwhile traditional market's visitors declining almost $8 \%$ every year (Pramono, et al. 2011).

In order to improve those number, Indonesian Ministry of Trade in 2017 targeting to revitalize 5.000 traditional markets for the next 5 years. The goal is to improve the traditional market facilities so the retailers of traditional could compete better with department store. The improvement of traditional market facilities is expected could improve the service quality of the market, so both the retailers and the customer have a better experience when visiting traditional market. In the long term, Indonesian Government hoping that traditional market could give a better impact on regional economy (Sistem Pemantauan Pasar Kebutuhan Pokok, 2016).

Market is a place where retailers are selling their goods and service directly to the customers. Revitalizing a market is an act to improving both the facilities and services of the market in order to give a good shopping experience (Masitoh, 2013). Kotler (2007) mentioned that retailing are any activities that sell goods and products directly to end user customer for personal and non-business intention, meanwhile retailer or retail store are any person or business ventures that doing retailing activities.

From marketing perspective, customer with a good experience would have higher intention to purchase the same products or revisit the store. Research conducted by $\mathrm{Wu}$ and $\mathrm{Li}$ (2014) on tourism heritage in Taiwan found that good tourism experience could 
improve the visitor's intention to revisit the heritage. In addition Sekarsari, et al. (2016) found that restaurant's customer experience could affect their loyalty.

There are some research modeling that customer's experience could affect customer perceived value and customer's loyalty (Brady and Cronin Jr, 2001; Clemes, et al., 2014; H-C. Wu, et al., 2016). Customer's perceived value and loyalty are 2 variables that are important in order to achieve customer's loyalty. In order to compare the service quality of traditional markets and department store, Arianty (2013) mentioned these items: cleanliness, good looking employee, uniformed employee, employee answer questions, market distance from customer's home, availability of restroom, restroom's cleanliness, convenient parking lot, precise cashier's return, quality of product, safety of product, no scamming, and the option for customer to compare product's prices.

\section{LITERATURE REVIEW}

Traditional market is defined as a place where merchant and buyer are meets and conduct transaction of goods or services, which the regulation and management is facilitated by regional government. The facilities provided in traditional market such as kiosks, stalls, shops or tents, those facilities are provided for any person or group those referred as small retailer (Indonesian President Regulation No. 112 Year 2007). Additional trait of traditional market is the customer could bargain the price of any goods and services sold in the market (Utomo, 2011). Nowadays, customer's experience is differentiated from customer's service quality and satisfaction (Verhoef, et al., 2009). Customer's experience is not only related to hedonic product consumption but also for any utilitarian products.

\section{Customer's Experience}

Customer's experience is derivated variable from the concept of customer's service quality. The variables has 3 dimensions, they are interaction quality, physical environment quality, and outcome quality (Brady and Cronin Jr, 2001). Interaction quality is defined as anything that related to relationship and interactions between retailers and 
customers on the process of buying goods or services. Customers will perceive the quality of those interactions mostly based on the performance from the retailers.

Physical environment quality defined as physical environment that supports the transactions of goods and services from retailers to customers. Brady and Cronin $\operatorname{Jr}$ (2001) mentioned the physical environment quality included ambient condition, facility design, and social factors. In addition, Clemes, Gan and Ren (2011) mentioned that physical environment quality mostly used by the customers to evaluate their experience quality when consuming goods and services. Outcome quality is defined as anything that is provided by the retailers when the transaction of goods and services is over. Outcome quality is the most valued factors by customers toward their experience quality of consuming goods or services.

The relationship of customer's experience quality and any other variables in marketing concept has been studied in some prior researches. Ren, Qiu, Wang, and Lin (2016) analyze the relationship of customer's service quality toward customer's satisfaction on Tiongkok's Hotel. The research found that higher customer's service quality could improve customer's satisfaction. Wu and $\mathrm{Wu}$ (2017) found similar results when applying the model on coffee store with and addition that customer's service quality could affect the customer's satisfaction. The research from $\mathrm{Wu}$ and $\mathrm{Wu}$ (2017) also found that good customer's satisfaction leads to customer's loyalty. In tourism industry, positive relationship between customer's service quality toward perceived value, customer's satisfaction, and loyalty is found on the research conducted by Chen and Chen (2010).

\section{Perceived Value}

In order to compete in the market, a company should be able to transfer good product value to their customer. A good perceived product value has a significant effect toward customer's satisfaction and customer loyalty. Customers with high satisfaction will ignore competitors offering and prefer to repurchase the same product from the company. Zeithaml (1998) mentioned that value is overall customer evaluation toward any goods and products that they consume. Bolton and Drew (1991) in Andreassen and Lindested (1996) previously describe that customer's perceived value affected by comparison of product cost and benefit, customer tastes, and customer characteristics. 
Lately, Kotler and Armstrong (2010) defined that perceived value is the comparison between total customer's value and total customer's cost. Customer's total value is a set of benefit that is expected by customers to be available on the products, meanwhile customer's total cost refers not only to the price of a product, but it also encompasses the purchase costs, use costs and the post-use costs.

Additional definition of perceived value by Zeithaml (1988) is a comparison between what customer get and what customer sacrifice. Dodds, Monroe, and Grewal (1991) mentioned the dimension of perceived value as:

1. "Get" is a term to show the benefit or quality that customer get from a product

2. "Sacrifice" is a term to show the price or cost that customer spend to get a product

\section{Visitor's Satisfaction}

Zeithaml, Bitner, and Gremier (2009) described satisfaction as customer's respond toward the fulfillment of their expectation based on the performance of the goods or services that they consumed. If the products performance could fulfills customer's expectation they will satisfied, but if not they will dissatisfied. Buchory and Saladin (2010) added that satisfaction is a pleased or unpleased feeling that is generated from comparing their expectation and performance of a product. Previously, Kotler (2006) describe satisfaction as the extent to which perceived performance of the products meets the customer's expectation.

Measuring customer's satisfaction is one act to evaluate company's position compared to competitors and company's image. Kotler and Armstrong (2010) stated there are 4 measurement methods in order to evaluate the customer's satisfaction, they are: complaint and suggestion system, customer's satisfaction surveys, ghost shopping and lost customer analysis. Some prior researches found the importance of customer's satisfaction. Tu, Li and Chih (2013) found that customer's satisfaction have significant effect toward customer's loyalty on shoe industries. Suhartanto, Clemes and Dean (2013) found similar results on Indonesian Hotel Industries, in addition this research found satisfied customer would revisit the hotel and recommend the hotel to their relatives. On 
transportation services, Hussein and Hapsari (2014) found that high level of customer's satisfaction has significant effect in improvement of Rapid Bus customer's loyalty in Jakarta. Recently, Hapsari, Clemes and Dean (2017) found similar results on customers of 5 stars airplane companies in Indonesia.

\section{Customer's Loyalty}

Nowadays customer's loyalty is one of marketing goals, the increasing of customer's loyalty is believed has big impact on company's image and revenue. Customer's loyalty described as customer behavior to repurchase a product (Jacoby and Kyner, 1973). The behavior including recommending the products to customer's relatives and giving a good description about the product and company to someone else, thus to measure customer's loyalty some recent researches included attitudinal loyalty as physiological factors that affect customer behavior. Reichheld (1992) added that maintaining customer's loyalty is harder to acquire the new one; therefore marketers tend to spending more budgets in customer's services after purchasing a product rather than creating a bigger advertisement.

Kotler and Armstrong (2010) defined that loyalty is a commitment of a customers to repurchase and support a product in the future. This commitment make customers tend to ignore any advertisement from competitors and giving a good description about the product to someone else. Kotler and Armstrong (2010) added there are 4 categories of customer loyalty, they are:

1. Hard core loyals, the group of customers that stay loyal to a products and ignore any advertisement from competitors and did not bother to repurchase the product even the price is more expensive than any substitute products.

2. Soft core loyals, the group of customers that quite loyal which is they have 2 preferred products and like to switch between those 2 .

3. Shifting loyal, the group of customer that like to switch from a brand to brand.

4. Switcher, the group of customer that is not loyal to any brand because they like to try newest products that is available on the market.

Griffin and Herres (2002) mention some benefit of having a loyal customers, such as decreasing advertisement cost, maintaining transaction and customer turn over, 
improving cross selling, provided positive word of mouth, and decreasing cost of failure. Griffin (2009) added customer's loyalty researches nowadays refer to behavioral conduct than attitudinal behavior. Attitudinal loyalty approach is measured based on how many times customer repurchase the product and not included physiological driven behavior which is ambiguous is it the real or fake loyalty (Dick and Basu, 1994). Bilgihan, Madanoglu, and Ricci (2016) recommended in order to precisely measuring customer's loyalty behavioral intention need to be added as one dimension of customer's loyalty.

\section{RESEARCH METHODS}

\section{Research Design}

This research is divided into 2 phases. The first research is conducted to exploring any dimension that construct traditional market's customer experience quality, which is will be used in the second research. The second research we analyzed the relationship between customer's experience, customer's satisfaction, perceived value and customer's loyalty. This research is developing an applicable model to improving the loyalty of traditional market's customers.

The first phase of the research, we conduct 2 times exploration research in the form of Focus Group Discussion (FGD) with traditional market's customers as the subject on the discussion. The results of the FGD is refined into a questionnaire draft that is distributed among traditional market's customer (excluded the customer on FGD). The data collected from the questionnaire is analyzed with Exploratory Factor Analyzed (EFA). The result from EFA is discussed with expertise in traditional market research before finally decided as traditional market customer's experiences construct.

The construct from the first phase of the research is used on the second phase research. The second research main purpose is to analyze the relationship between experience quality, customer's satisfaction, perceived value, and customer's loyalty. The second research is conducted by distributing questionnaires to traditional market's customers (excluded the customer on the first phase research). The results of the survey will be analyzing using Structural Equation Modeling (SEM). The results from both research is expected could giving a clear explanation about the relationship between the 
variables and could be help government to make decisions in order to improve the loyalty of traditional market's customers based on customer's experience quality.

\section{Population and Sample}

The populations of this research are traditional market's customers in Malang City, Indonesia that come to the traditional market with their own intention. The sampling method used is convenience sampling methods. In order to get a good quality data from FGD, we included marketing expertise and market's retailer in our FGD to giving opinion about the traditional market customer's experience quality.

\section{Data Collection Methods}

The Focus Group Discussion is divided into 2 session with 6 and 9 customers of traditional market. To facilitate the discussion, we invite a market expertise and a market retailer to giving opinion from their point of view about customer's experience. The second phase of the research is conducted in traditional market all around Malang City, Indonesia. Because of the unclear number of traditional market's customers, we decided to use convenience sampling methods (Sekaran, 2000). We finally used 250 traditional market's customers as our sample in order to fulfill the requirement of SEM analysis. The results of second phase research is discussed with traditional market's customers, retailers and market academics in a form of FGD in order to find a clear explanation of the results found in this research.

\section{RESULTS and DISCUSSION}

\section{Exploratory Factor Analysis}

The first phase of the research was analyzed using Exploratory Factor Analysis (EFA). Firstly we collect data from FGD and refine the data into questionnaire. We divided the data into 7 dimension, they are: Physical Quality, Willingness to Serve, Valences, Product Quality, Social Interaction, Accessibility, and Product Knowledge. After refined the data into questionnaire, we distribute the questionnaire to traditional market's customer and analyze the collected data into EFA and found the Pattern Matrix shown in Table 1. 
Table 1.

Pattern Matrix

Rotated Component Matrix ${ }^{a}$

\begin{tabular}{|c|c|c|c|c|c|c|c|}
\hline & \multicolumn{7}{|c|}{ Component } \\
\hline & 1 & 2 & 3 & 4 & 5 & 6 & 7 \\
\hline EQ1 & .075 & .667 & .194 & .098 & -.050 & .189 & .042 \\
\hline EQ2 & .161 & .760 & .099 & -.045 & .080 & .083 & .036 \\
\hline EQ3 & .224 & .827 & -.004 & .006 & .057 & .054 & -.019 \\
\hline EQ4 & .155 & .763 & .083 & .148 & .008 & .003 & .145 \\
\hline EQ5 & .110 & .347 & -.028 & .352 & .101 & -.063 & .548 \\
\hline EQ6 & .152 & .055 & .078 & .030 & -.127 & .002 & .761 \\
\hline EQ7 & .603 & .252 & .049 & -.146 & -.028 & -.065 & .385 \\
\hline EQ8 & .777 & .078 & .020 & .014 & .043 & .014 & .280 \\
\hline EQ9 & .792 & .066 & .009 & .070 & .065 & .003 & -.037 \\
\hline EQ10 & .537 & .141 & .158 & .384 & -.136 & .136 & -.260 \\
\hline EQ11 & .533 & .285 & .198 & .367 & -.047 & .209 & -.220 \\
\hline EQ12 & .820 & .182 & .014 & .271 & .020 & .034 & .083 \\
\hline EQ13 & .848 & .155 & -.018 & .264 & -.016 & -.045 & -.038 \\
\hline EQ14 & .245 & .121 & .288 & .682 & .044 & .210 & .078 \\
\hline EQ15 & .058 & -.077 & .437 & .027 & .130 & .360 & .452 \\
\hline EQ16 & .129 & .035 & .387 & .568 & .265 & .138 & .231 \\
\hline EQ17 & .200 & -.002 & .280 & .457 & .029 & .221 & .399 \\
\hline EQ18 & .684 & .127 & .198 & .026 & -.044 & .206 & .065 \\
\hline EQ19 & .558 & .005 & .414 & -.126 & .085 & .018 & .173 \\
\hline EQ20 & .489 & .276 & .237 & -.279 & .128 & .329 & .088 \\
\hline EQ21 & .133 & .235 & .719 & .351 & .117 & .011 & -.029 \\
\hline EQ22 & .033 & .058 & .741 & .171 & .179 & .196 & .066 \\
\hline
\end{tabular}




\begin{tabular}{|l|l|l|l|l|l|l|l|} 
EQ23 & .162 & .202 & .807 & .087 & .149 & .068 & .057 \\
EQ24 & .108 & .000 & .340 & .197 & .590 & .001 & .041 \\
EQ25 & -.046 & .042 & .030 & .088 & .799 & .107 & -.010 \\
EQ26 & .138 & .044 & .179 & -.120 & .789 & -.048 & -.068 \\
EQ27 & .721 & .051 & .098 & .093 & .203 & .278 & .088 \\
EQ28 & .539 & .148 & .125 & .157 & .224 & .293 & .168 \\
EQ29 & .140 & .224 & .121 & .034 & .017 & .774 & -.045 \\
EQ30 & .157 & .053 & .104 & .318 & .021 & .700 & .055 \\
\hline
\end{tabular}

Extraction Method: Principal Component Analysis.

Rotation Method: Varimax with Kaiser Normalization.

a. Rotation converged in 9 iterations.

Source: Analyzed Data, 2017

Based on the Table 1, there are 30 items of traditional market customer's experience quality, which will be grouped into 7 indicators which is shown in Table 2 .

Table 2.

\section{Redistribution of Experience Quality's Items into 7 Dimensions}

\begin{tabular}{|l|l|l|}
\hline Factors & Question & New Dimension \\
\hline $1(12$ item $)$ & $\begin{array}{l}\text { EQ7, EQ8, EQ9, EQ10, EQ11, EQ12, } \\
\text { EQ13, EQ18, EQ19, EQ20, EQ27, } \\
\text { EQ28 }\end{array}$ & Physical Quality \\
\hline $2(4$ item $)$ & EQ1, EQ2, EQ3, EQ4 & Willingness to Serve \\
\hline $3(3$ item $)$ & EQ21, EQ22,EQ23 & Valences \\
\hline $4(3$ item $)$ & EQ14, EQ16, EQ17 & Product Quality \\
\hline $5(3$ item) & EQ24, EQ25, EQ26 & Social Interaction \\
\hline $6(2$ item $)$ & EQ29, EQ30 & Product Knowledge \\
\hline $7(3$ item $)$ & EQ5, EQ6, EQ15 & \\
\hline
\end{tabular}

Source: Analyzed Data, 2017

The finding on first phase research will be used in the second research as new dimension construct for customer's experience quality (EQ). In addition, we determined 
the others variables items based on some prior researches. Customer's Loyalty (BI) has 4 items, they are: loyalty of shopping in the market (BI1); intention to invite other people to shopping in the market (BI2); recommending market into other people (BI3); and giving positive feedbacks about market into other people (BI4). Perceived Value (PV) consist of 4 items, they are: comparing the cost of going into market and benefit of the products (PV1); considering reasonable product prices (PV2); purchased product suited to the prices paid (PV3); and benefit value of shopping in the market (PV4) . Visitor's Satisfaction is measured by 3 items, they are overall satisfaction of shopping in the market (VS1); pleased feeling in the market (VS2); and sensibility of the decision to shopping in the market (VS3).

\section{Outer Model Analyzes}

Outer model analyzes conducted in order to find out the loading factor of each item in the variables on the model. The loading factor value is used to determine the convergent and discriminant validity of the items. In addition we could find the value of composite reliability and cronbach alpha of the variable in order to evaluate the reliability of the model itself. The outer model of this research is shown in Figure 1.

\section{Figure 1.}

\section{Outer Model Analyzes}

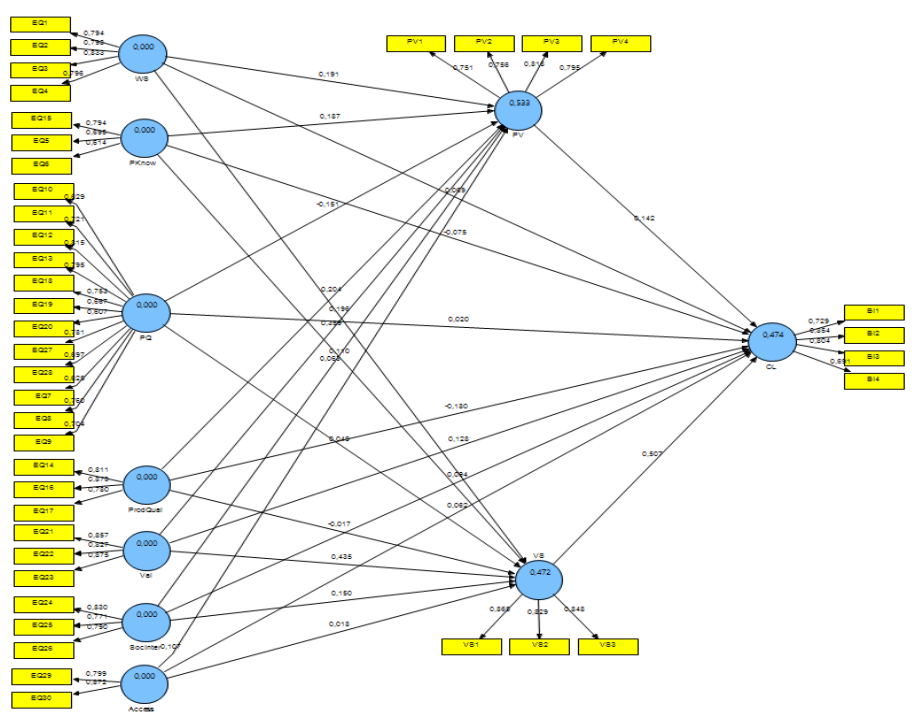


Source: Analyzed Data, 2017

\section{Convergent Validity}

Based on the Figure 1, we could refined the scheme into simple table as shown in Table 3. Tan and Sitompul (2014) stated an item has a convergent validity if the value of the loading factors above 0.5 . As we can see, each items on the research has loading factors value above 0.5 which indicated that all of the item from all the variables pass the requirement of convergent validity.

Table 3.

\section{Loading Factors Value}

\begin{tabular}{|l|l|l|}
\hline Item & Loading Factors & Description \\
\hline $\begin{array}{l}\text { EQ1 <- Willingness to } \\
\text { Serve }\end{array}$ & 0.794024 & Valid \\
\hline $\begin{array}{l}\text { EQ2 <- Willingness to } \\
\text { Serve }\end{array}$ & 0.797805 & Valid \\
\hline $\begin{array}{l}\text { EQ3 <- Willingness to } \\
\text { Serve }\end{array}$ & 0.832748 & Valid \\
\hline $\begin{array}{l}\text { EQ4 <- Willingness to } \\
\text { Serve }\end{array}$ & 0.795915 & Valid \\
\hline $\begin{array}{l}\text { EQ5 <- Product } \\
\text { Knowledge }\end{array}$ & 0.694961 & Valid \\
\hline $\begin{array}{l}\text { EQ6 <- Product } \\
\text { Knowledge }\end{array}$ & 0.614189 & Valid \\
\hline EQ7 <- Physical Quality & 0.624934 & Valid \\
\hline EQ8 <- Physical Quality & 0.760137 & Valid \\
\hline EQ9 <- Physical Quality & 0.703543 & Valid \\
\hline EQ10 <- Physical Quality & 0.628636 & Valid \\
\hline EQ11 <- Physical Quality & 0.720794 & Valid \\
\hline EQ12 <-Physical Quality & 0.815487 & Valid \\
\hline $\begin{array}{l}\text { EQ13 <- Physical Quality } \\
\text { EQ14 <- Product Quality }\end{array}$ & 0.795475 & 0.810572 \\
\hline
\end{tabular}




\begin{tabular}{|c|c|c|}
\hline Item & Loading Factors & Description \\
\hline $\begin{array}{l}\text { EQ15 <- Product } \\
\text { Knowledge }\end{array}$ & 0.793657 & Valid \\
\hline EQ16 <- Product Quality & 0.872519 & Valid \\
\hline EQ17 <- Product Quality & 0.779958 & Valid \\
\hline EQ18 <- Physical Quality & 0.752729 & Valid \\
\hline EQ19 <- Physical Quality & 0.666648 & Valid \\
\hline EQ20 <- Physical Quality & 0.60656 & Valid \\
\hline EQ21 <- Valences & 0.856624 & Valid \\
\hline EQ22 <- Valences & 0.827151 & Valid \\
\hline EQ23 <- Valences & 0.874882 & Valid \\
\hline EQ24 <- Social Interaction & 0.829578 & Valid \\
\hline EQ25 <- Social Interaction & 0.77102 & Valid \\
\hline EQ26 <- Social Interaction & 0.790016 & Valid \\
\hline EQ27 <- Physical Quality & 0.781192 & Valid \\
\hline EQ28 <- Physical Quality & 0.69691 & Valid \\
\hline EQ29 <-Accessibility & 0.799015 & Valid \\
\hline EQ30 <- Accessibility & 0.872112 & Valid \\
\hline BI1 <- Customer Loyalty & 0.728608 & Valid \\
\hline BI2 <- Customer Loyalty & 0.854431 & Valid \\
\hline BI3 <- Customer Loyalty & 0.8038 & Valid \\
\hline BI4 <- Customer Loyalty & 0.690897 & Valid \\
\hline PV1 <- Perceived Value & 0.750727 & Valid \\
\hline PV2 <- Perceived Value & 0.756266 & Valid \\
\hline PV3 <- Perceived Value & 0.818236 & Valid \\
\hline PV4 <- Perceived Value & 0.794616 & Valid \\
\hline VS1 <- Visitor Satisfaction & 0.865387 & Valid \\
\hline VS2 <- Visitor Satisfaction & 0.828676 & Valid \\
\hline VS3 <- Visitor Satisfaction & 0.847949 & Valid \\
\hline
\end{tabular}


Source: Analyzed Data, 2017

\section{Discriminant Validity}

Discriminant validity analyzes is used in order to make sure that the items from any variables is suited best for the variable it is generated rather than other variables. This analyzed could be conducted by comparing the loading factors value of the items across other variables. If the loading factors value of the items is higher when it is tested on the variable itself rather than on other variables in the model, that item is passed the discriminant validity requirement (Hussein, 2017). On the Table 4, we could see the cross loading factors of the items in the research model.

\section{Table 4}

\section{Cross Loading Factors of Each Items}

\begin{tabular}{|l|l|l|l|l|l|l|l|l|l|l|}
\hline & $\begin{array}{l}\text { Acce } \\
\text { ss }\end{array}$ & $\mathbf{C L}$ & $\begin{array}{l}\text { PKno } \\
\mathbf{w}\end{array}$ & $\mathbf{P Q}$ & $\mathbf{P V}$ & $\begin{array}{l}\text { Prod } \\
\text { Qual }\end{array}$ & $\begin{array}{l}\text { SocIn } \\
\text { ter }\end{array}$ & $\mathbf{V S}$ & Val & WS \\
\hline BI1 & 0.197 & 0.729 & 0.156 & 0.147 & 0.358 & 0.224 & 0.347 & 0.564 & 0.389 & 0.231 \\
\hline BI2 & 0.177 & 0.854 & 0.205 & 0.262 & 0.351 & 0.174 & 0.227 & 0.527 & 0.389 & 0.266 \\
\hline BI3 & 0.254 & 0.804 & 0.132 & 0.255 & 0.376 & 0.164 & 0.187 & 0.462 & 0.358 & 0.271 \\
\hline BI4 & 0.168 & 0.691 & 0.229 & 0.198 & 0.374 & 0.187 & 0.179 & 0.448 & 0.353 & 0.337 \\
\hline EQ1 & 0.267 & 0.309 & 0.277 & 0.314 & 0.394 & 0.340 & 0.117 & 0.416 & 0.344 & 0.794 \\
\hline EQ10 & 0.334 & 0.247 & 0.157 & 0.629 & 0.220 & 0.335 & 0.123 & 0.204 & 0.249 & 0.285 \\
\hline EQ11 & 0.382 & 0.237 & 0.247 & 0.721 & 0.281 & 0.423 & 0.142 & 0.369 & 0.366 & 0.475 \\
\hline EQ12 & 0.284 & 0.171 & 0.289 & 0.815 & 0.167 & 0.399 & 0.121 & 0.273 & 0.261 & 0.361 \\
\hline EQ13 & 0.214 & 0.148 & 0.189 & 0.795 & 0.102 & 0.317 & 0.106 & 0.229 & 0.202 & 0.312 \\
\hline EQ14 & 0.405 & 0.205 & 0.404 & 0.460 & 0.412 & 0.811 & 0.198 & 0.389 & 0.482 & 0.333 \\
\hline EQ15 & 0.285 & 0.194 & 0.794 & 0.208 & 0.447 & 0.461 & 0.288 & 0.343 & 0.371 & 0.192 \\
\hline EQ16 & 0.340 & 0.213 & 0.434 & 0.344 & 0.479 & 0.873 & 0.362 & 0.411 & 0.525 & 0.254 \\
\hline EQ17 & 0.367 & 0.184 & 0.429 & 0.343 & 0.517 & 0.780 & 0.137 & 0.265 & 0.423 & 0.265 \\
\hline EQ18 & 0.291 & 0.195 & 0.222 & 0.753 & 0.211 & 0.318 & 0.175 & 0.252 & 0.284 & 0.258 \\
\hline EQ19 & 0.232 & 0.171 & 0.246 & 0.667 & 0.258 & 0.325 & 0.240 & 0.341 & 0.384 & 0.260 \\
\hline EQ2 & 0.204 & 0.296 & 0.296 & 0.314 & 0.346 & 0.207 & 0.161 & 0.344 & 0.279 & 0.798 \\
\hline EQ20 & 0.252 & 0.195 & 0.202 & 0.607 & 0.184 & 0.200 & 0.210 & 0.267 & 0.318 & 0.347 \\
\hline EQ21 & 0.312 & 0.374 & 0.352 & 0.352 & 0.535 & 0.543 & 0.260 & 0.522 & 0.857 & 0.390 \\
\hline
\end{tabular}




\begin{tabular}{|c|c|c|c|c|c|c|c|c|c|c|}
\hline EQ22 & 0.334 & 0.408 & 0.328 & 0.281 & 0.535 & 0.468 & 0.340 & 0.469 & 0.827 & 0.192 \\
\hline EQ23 & 0.324 & 0.455 & 0.321 & 0.401 & 0.527 & 0.479 & 0.244 & 0.587 & 0.875 & 0.380 \\
\hline EQ24 & 0.135 & 0.217 & 0.294 & 0.233 & 0.292 & 0.277 & 0.830 & 0.358 & 0.339 & 0.122 \\
\hline EQ25 & 0.127 & 0.192 & 0.213 & 0.095 & 0.237 & 0.243 & 0.771 & 0.181 & 0.202 & 0.121 \\
\hline EQ26 & 0.053 & 0.326 & 0.094 & 0.223 & 0.166 & 0.169 & 0.790 & 0.287 & 0.223 & 0.096 \\
\hline EQ27 & 0.368 & 0.203 & 0.259 & 0.781 & 0.240 & 0.422 & 0.240 & 0.286 & 0.331 & 0.263 \\
\hline EQ28 & 0.425 & 0.219 & 0.355 & 0.697 & 0.270 & 0.422 & 0.241 & 0.319 & 0.372 & 0.331 \\
\hline EQ29 & 0.799 & 0.206 & 0.221 & 0.343 & 0.306 & 0.307 & 0.070 & 0.201 & 0.321 & 0.289 \\
\hline EQ3 & 0.252 & 0.288 & 0.235 & 0.431 & 0.308 & 0.239 & 0.126 & 0.345 & 0.274 & 0.833 \\
\hline EQ30 & 0.872 & 0.226 & 0.284 & 0.339 & 0.352 & 0.434 & 0.141 & 0.302 & 0.316 & 0.213 \\
\hline EQ4 & 0.218 & 0.243 & 0.369 & 0.372 & 0.358 & 0.313 & 0.044 & 0.310 & 0.315 & 0.796 \\
\hline EQ5 & 0.170 & 0.179 & 0.695 & 0.342 & 0.317 & 0.316 & 0.126 & 0.318 & 0.271 & 0.420 \\
\hline EQ6 & 0.169 & 0.096 & 0.614 & 0.206 & 0.247 & 0.276 & 0.064 & 0.141 & 0.118 & 0.148 \\
\hline EQ7 & 0.126 & 0.182 & 0.279 & 0.625 & 0.215 & 0.165 & 0.108 & 0.198 & 0.176 & 0.296 \\
\hline EQ8 & 0.202 & 0.244 & 0.316 & 0.760 & 0.174 & 0.260 & 0.140 & 0.255 & 0.181 & 0.252 \\
\hline EQ9 & 0.203 & 0.026 & 0.166 & 0.704 & 0.038 & 0.225 & 0.147 & 0.155 & 0.152 & 0.238 \\
\hline PV1 & 0.294 & 0.373 & 0.369 & 0.240 & 0.751 & 0.449 & 0.199 & 0.515 & 0.538 & 0.348 \\
\hline PV2 & 0.326 & 0.339 & 0.368 & 0.199 & 0.756 & 0.396 & 0.189 & 0.295 & 0.379 & 0.328 \\
\hline PV3 & 0.333 & 0.341 & 0.432 & 0.245 & 0.818 & 0.508 & 0.224 & 0.452 & 0.474 & 0.339 \\
\hline PV4 & 0.284 & 0.415 & 0.381 & 0.243 & 0.795 & 0.425 & 0.291 & 0.576 & 0.539 & 0.355 \\
\hline VS1 & 0.254 & 0.546 & 0.393 & 0.297 & 0.567 & 0.387 & 0.308 & 0.865 & 0.560 & 0.424 \\
\hline VS2 & 0.256 & 0.470 & 0.305 & 0.431 & 0.404 & 0.382 & 0.304 & 0.829 & 0.497 & 0.410 \\
\hline VS3 & 0.268 & 0.637 & 0.325 & 0.267 & 0.537 & 0.337 & 0.297 & 0.848 & 0.514 & 0.298 \\
\hline
\end{tabular}

Notes: Access= Accessibility; $C L=$ Customer's Loyalty; PKnow= Product Knowledge; $P Q=$ Physical Quality; PV= Perceived Value; ProdQual= Product Quality; SocInter= Social Interaction; VS=Visitor's Satisfaction; Val=Valences; WS=Willingness to Serve.

Source: Analyzed Data, 2017 


\section{Composite Reliability}

Composite reliability is a measurement of the model construction strength. A good model construct has alpha cronbach and composite reliability value more than 0.6 (Hair, et al., 2010). The value of each indicators alpha cronbach and composite reliability is shown on Table 5 . All of the indicators have more than 0.6 composite reliability value; these results suggest that all indicators is considered reliable in building a good construction model.

Table 5.

Value of Cronbach Alpha and Composite Reliability

\begin{tabular}{|l|l|l|}
\hline Variabel & Cronbach's Alpha & CompositeReliability \\
\hline Physical Quality & 0.913028 & 0.925962 \\
\hline Willingness to Serve & 0.81983 & 0.880614 \\
\hline Valences & 0.812895 & 0.889099 \\
\hline Product Quality & 0.758579 & 0.925962 \\
\hline Social Interaction & 0.717228 & 0.839429 \\
\hline Accessibility & 0.574081 & 0.822906 \\
\hline Product Knowledge & 0.515054 & 0.745451 \\
\hline Customer Loyalty & 0.771351 & 0.85429 \\
\hline Perceived Value & 0.785945 & 0.861596 \\
\hline Visitor Satisfaction & 0.804005 & 0.884308 \\
\hline
\end{tabular}

Source: Analyzed Data, 2017

\section{Inner Model Analyzes}

Inner model analyzes is conducted to measure the accuracy and robustness of the structural model (Hussein, 2017). The accuracy of the model is measured by analyzing the coefficient of determination $\left(\mathrm{R}^{2}\right)$, meanwhile the robustness of the model is measured by analyzing the predictive relevance $\left(\mathrm{Q}^{2}\right)$. The inner model of this research is shown on Figure 2. 
Figure 2.

\section{Inner Model Analyzes}

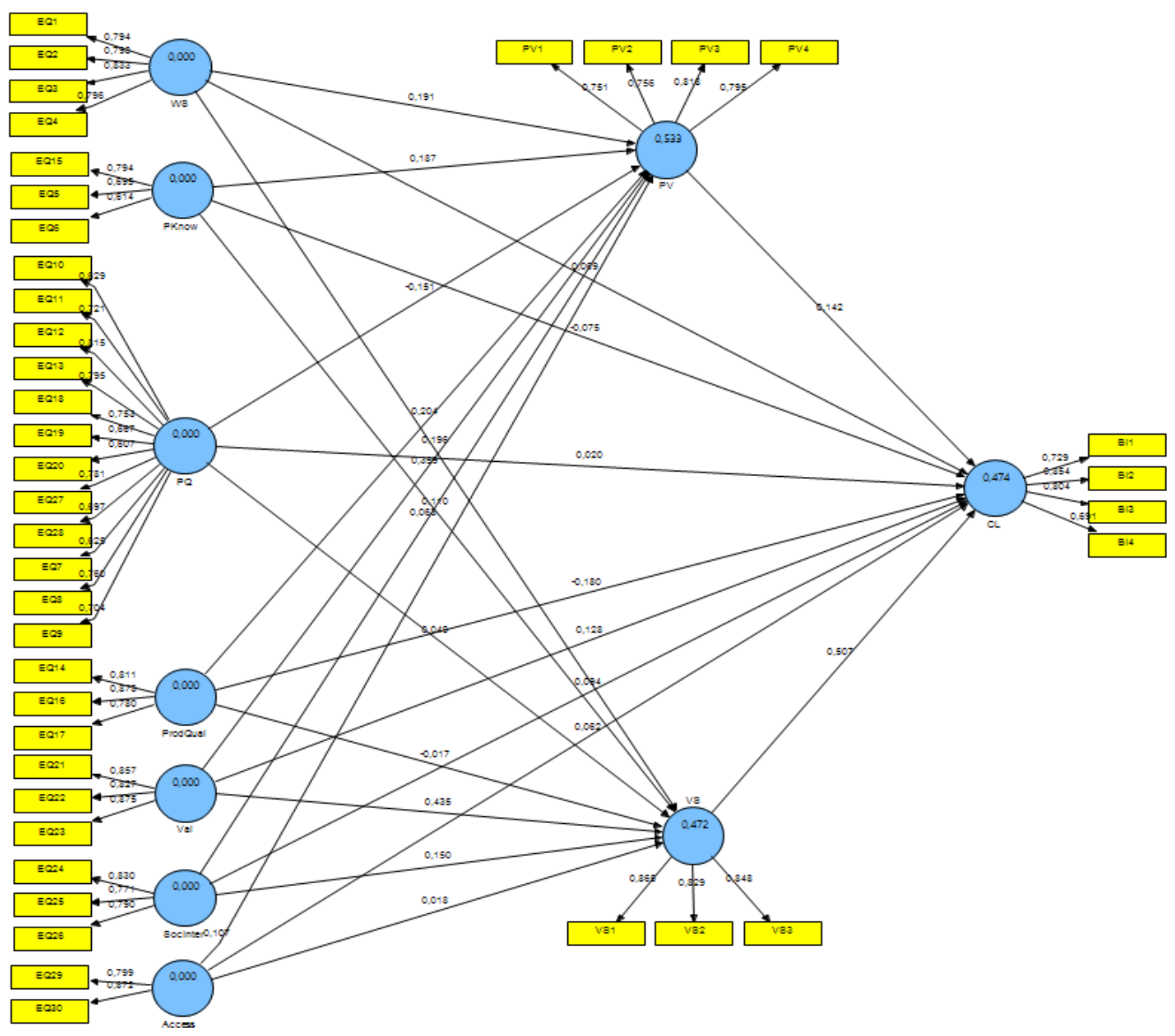

Source: Analyzed Data, 2017

\section{Coefficient of Determination $\left(\mathbf{R}^{2}\right)$}

There is no any limitation of $\mathrm{R}^{2}$ value (Hussein, 2017). However Gotz in Hussein (2017) added higher value of $\mathrm{R}^{2}$ indicates a better structural model. From the Figure 2, we could see customer's loyalty has $\mathrm{R}^{2}$ value of 0.474 which mean customer's loyalty is determined by experience quality, perceived value and visitor's satisfaction about $47.4 \%$ meanwhile there are other variables that is not on this research determined the customer's loyalty about $52.6 \%$. Perceived Value has $0.532 \mathrm{R}^{2}$ value which indicates that experience quality determined perceived value by $52.2 \%$ with additional $47.8 \%$ is determined by 
other variables not included in the research. Visitor's satisfaction has $0.471 \mathrm{R}^{2}$ value which indicates the variables is determined by experience quality about $47.1 \%$ meanwhile the rest $42.9 \%$ is determined by other variables.

\section{Predictive Relevance $\left(\mathrm{Q}^{2}\right)$}

The robustness of a structural model is measured by finding the $\mathrm{Q}^{2}$ of the model. The calculation and results of the $\mathrm{Q}^{2}$ of the model is shown in Table 6 . The value of $\mathrm{Q}^{2}$ is within 0 and 1 , if the $\mathrm{Q}^{2}$ of the model is nearly 1 the model has a good construct because it is more likely to illustrate the relationship between the variables in the model. The value of $\mathrm{Q}^{2}$ in the model is 0.869 which indicates that the model could describe the relationship between the variables about $86.9 \%$ with the rest of $13.1 \%$ is another variables that is not included in the research.

Table 6.

Predictive Relevance $\left(\mathbf{Q}^{2}\right)$

\begin{tabular}{|c|c|}
\hline Variable & R-Square $\left(\mathbf{R}^{2}\right)$ \\
\hline Customer Loyalty & 0.474069 \\
\hline Perceived Value & 0.532755 \\
\hline Visitor Satisfaction & 0.471505 \\
\hline \multicolumn{2}{|c|}{$Q^{2}=1-\left(\left(1-R^{2}\right)\left(1-R^{2}\right)\left(1-R^{2}\right)\left(1-R^{2}\right) \square Q^{2}=1-(0,526)(0,468)(0,529)=0,869\right.$} \\
\hline
\end{tabular}

Source: Analyzed Data, 2017

\section{Hypotheses Analyzes}

The relationship between variables could be determined by comparing the $\mathrm{t}$ statistics value and t-table value. If the t-statistics of a relationship between variables is more than 1.96 (t-table), the independent variables has significant effect toward dependent variables and vise versa. In Table 7 we could see the value of each relationship of the variables in the model. 
Table 7.

Hypotheses Analyzes

\begin{tabular}{|c|c|c|c|c|c|c|}
\hline Hypotheses & Variable & $\begin{array}{l}\text { Original } \\
\text { Sample } \\
\text { (O) }\end{array}$ & $\begin{array}{l}\text { Sample } \\
\text { Mean } \\
\text { (M) }\end{array}$ & $\begin{array}{l}\text { Standard } \\
\text { Deviation } \\
\text { (STDEV) }\end{array}$ & $\begin{array}{l}\text { Standard } \\
\text { Error } \\
\text { (STERR) }\end{array}$ & $\begin{array}{l}\text { T Statistics } \\
(\mid \text { O/STERR } \mid)\end{array}$ \\
\hline H1 & Access $->$ CL & 0.062 & 0.061 & 0.080 & 0.080 & 0.775 \\
\hline H2 & Access -> PV & 0.107 & 0.105 & 0.065 & 0.065 & 1.651 \\
\hline H3 & Access -> VS & 0.018 & 0.021 & 0.083 & 0.083 & 0.216 \\
\hline H4 & $\begin{array}{l}\text { PKnow -> } \\
\text { CL }\end{array}$ & -0.075 & -0.068 & 0.072 & 0.072 & 1.040 \\
\hline H5 & $\begin{array}{l}\text { PKnow -> } \\
\text { PV }\end{array}$ & 0.187 & 0.195 & 0.063 & 0.063 & 2.969 \\
\hline H6 & $\begin{array}{l}\text { PKnow -> } \\
\text { VS }\end{array}$ & 0.110 & 0.105 & 0.080 & 0.080 & 1.375 \\
\hline H7 & $P Q$-> CL & 0.020 & 0.022 & 0.068 & 0.068 & 0.287 \\
\hline H8 & $P Q$-> PV & -0.151 & -0.143 & 0.056 & 0.056 & 2.696 \\
\hline H9 & $P Q$-> VS & 0.049 & 0.046 & 0.078 & 0.078 & 0.627 \\
\hline H10 & PV $>$ CL & 0.142 & 0.130 & 0.092 & 0.092 & 1.545 \\
\hline H11 & $\begin{array}{l}\text { ProdQual -> } \\
\text { CL }\end{array}$ & -0.180 & -0.175 & 0.082 & 0.082 & 2.202 \\
\hline H12 & $\begin{array}{l}\text { ProdQual -> } \\
\text { PV }\end{array}$ & 0.204 & 0.194 & 0.085 & 0.085 & 2.393 \\
\hline H13 & $\begin{array}{l}\text { ProdQual -> } \\
\text { VS }\end{array}$ & -0.017 & -0.019 & 0.087 & 0.087 & 0.200 \\
\hline H14 & $\begin{array}{l}\text { SocInter -> } \\
\text { CL }\end{array}$ & 0.094 & 0.081 & 0.077 & 0.077 & 1.219 \\
\hline H15 & $\begin{array}{l}\text { SocInter -> } \\
\text { PV }\end{array}$ & 0.063 & 0.065 & 0.055 & 0.055 & 1.150 \\
\hline H16 & $\begin{array}{l}\text { SocInter -> } \\
\text { VS }\end{array}$ & 0.150 & 0.157 & 0.073 & 0.073 & 2.049 \\
\hline H17 & VS -> CL & 0.507 & 0.509 & 0.094 & 0.094 & 5.374 \\
\hline H18 & Val -> CL & 0.128 & 0.140 & 0.086 & 0.086 & 1.480 \\
\hline
\end{tabular}




\begin{tabular}{|l|l|l|l|l|l|l|}
\hline Hypotheses & Variable & $\begin{array}{l}\text { Original } \\
\text { Sample } \\
(\mathbf{O})\end{array}$ & $\begin{array}{l}\text { Sample } \\
\text { Mean } \\
(\mathbf{M})\end{array}$ & $\begin{array}{l}\text { Standard } \\
\text { Deviation } \\
(\text { STDEV) }\end{array}$ & $\begin{array}{l}\text { Standard } \\
\text { Error } \\
(\text { STERR) }\end{array}$ & $\begin{array}{l}\text { T Statistics } \\
(\mid \mathbf{O} \text { (STERR })\end{array}$ \\
\hline H19 & Val -> PV & 0.359 & 0.359 & 0.075 & 0.075 & 4.796 \\
\hline H20 & Val -> VS & 0.435 & 0.434 & 0.083 & 0.083 & 5.274 \\
\hline H21 & WS -> CL & 0.069 & 0.069 & 0.091 & 0.091 & 0.757 \\
\hline H22 & WS -> PV & 0.191 & 0.192 & 0.053 & 0.053 & 3.610 \\
\hline H23 & WS -> VS & 0.196 & 0.201 & 0.077 & 0.077 & 2.563 \\
\hline
\end{tabular}

Keterangan tabel: Access = Accessibility; CL: Customer's Loyalty; Pknow: Product Knowledge; PQ: Phisical Quality; PV: Perceived Value; ProdQual: Product Quality; SocInter: Social Interaction; VS: Visitor's Satisfaction; Val: Valences; WS: Willingness to Serve.

Source: Analyzed Data, 2017

Based on Table 7 there are 6 hypotheses are rejected, they are: H1 which shown that accessibility has no significant effect toward customer's loyalty; H3 which shown that accessibility has no significant effect toward visitor's satisfaction; H7 which shown that physical quality has no significant effect toward customer's loyalty; H9 which shown that physical quality has no significant effect toward visitor's satisfaction; H13 which shown that product quality has no significant effect toward visitor's satisfaction; and H21 which shown that willingness to serve has no significant effect toward customer's loyalty.

\section{Mediation Testing}

We conducted mediation testing in order to analyze the role of visitor's satisfaction and perceived value as mediation variables between the relationship of experience quality and customer's loyalty. The result of the test is shown in Table 8. V47 is the mean of perceived value and V43 is the mean of visitor's satisfaction. V47 has signification value of 0.000 and V43 has signification value of 0.071 . We used online calculation on www.danielscoper.com to do the sobel test. 
Table 8.

Coefficient of Regression Test

Coefficients

\begin{tabular}{|l|l|l|l|l|l|}
\hline \multirow{2}{*}{ Model } & \multicolumn{2}{|l|}{ Unstandardized Coefficients } & Standardized Coefficients & & \\
\cline { 2 - 5 } & $\mathrm{B}$ & Std. Error & Beta & $\mathrm{t}$ & Sig. \\
\hline 1 (Constant) & 1.277 & .211 & & 6.050 & .000 \\
V47 & .501 & .055 & .558 & 9.143 & .000 \\
V43 & .120 & .066 & .111 & 1.810 & .071 \\
\hline
\end{tabular}

a. Dependent Variable: V52

Source: Analyzed Data, 2017

To figure out whether a variable could mediated a relationship is to find out the $\mathrm{Z}$ value. If the $\mathrm{Z}$ value is more than 1.96 the variables could mediate the relationship between 2 variables. Perceived value and visitor's satisfaction are found could be mediated the relationship between experience quality and customer's loyalty because of $\mathrm{Z}$ value that exceeds 1.96 based on this calculation:

$$
\begin{aligned}
& \mathrm{Sab} \quad=\sqrt{\mathrm{b}^{2} \mathrm{Sa}^{2}+\mathrm{a}^{\mathrm{D}} \mathrm{Sb}^{2}+\mathrm{Sa}^{2} \mathrm{Sb}^{2}} \\
& \begin{array}{c}
=\sqrt{0.04356+0.00109+0.00131} \\
=\sqrt{0.04596}
\end{array}
\end{aligned}
$$

$=0.2143828351$

Therefore, $\mathrm{Z}=\frac{\mathrm{ab}}{\mathrm{Sab}}=\frac{0.501 \times 0.120}{0.2143828351}=0,2804328993$

\section{DISCUSSION}

Based on hypotheses results there are 6 out of 23 hypotheses is not significant, they are accessibility and customer's loyalty; accessibility and visitor's satisfaction; physical quality and customer's loyalty; physical quality and visitor's satisfaction; product quality and visitor's satisfaction; and willingness to serve and customer's loyalty. Those 
results shown that accessibility is not a strong factor that could affect customer satisfaction and loyalty. Social interaction, customer's experience and quality of product is considered more important factors that could affect customer's loyalty and satisfaction, therefore these variables should getting more attention both from government and traditional market retailers if they want to improve the satisfaction and loyalty of their customers.

Second results found that physical quality could not affect customer's loyalty and satisfaction. The results shown that customer's experience and social interaction between the customer and retailers is considered more important factors that could affect customer's loyalty and satisfaction. According to Brady and Cronin Jr (2001) there are 3 dimension of experience quality, they are interaction quality, physical environment quality and outcome quality. Interaction quality defined as the interaction between the retailers and customers. Physical environment quality is referred as physical environment that support the purchasing process between customers and retailer, and outcome quality is the overall evaluation toward the purchasing process between the customer and retailers in the end of the process. The government and traditional market's retailers should pay more attention toward the interaction in the traditional market in order to improve the customer's loyalty and satisfaction because from the 3 dimensions mentioned before, interaction quality is more important than the other 2 based on this research results.

Lastly the quality of product could not affect customer's satisfaction. As mentioned by Brady and Cronin Jr (2001) the quality of interaction is very important which made the quality of the product itself could not improve customer's satisfaction. In addition a good service quality could be a good approach in order to improving overall customer satisfaction. This research found that perceived value and customer's satisfaction could mediate the relationship between customer's experience qualities toward customer's loyalty. According to Kotler and Armstrong (2010) perceived value is a comparison between total customer's value and total customer's cost. Customer's total value is a set of benefit that is expected by customers to be available on the products; therefore market's retailers in traditional market should pay attention toward customer's expectation of their products and delivered the value of the product precisely to their customers. 


\section{CONCLUSION}

According to the findings on this study, the accesibility of a traditional market is not a significant factor that could affect customer satisfaction or loyalty. This mean that the customer didn't pay too much attention toward the accesibility of traditional market, however social interaction and the quality of product is considered to be very important in order to build a customer satisfaction and loyalty. Among the 3 dimension of experience quality, customer of a traditional market is considering interaction quality as the most important dimension in order to improve their satisfaction and loyalty, they don't really mind the physical and outcome quality of a traditional market.

Finally this researh found that perceived value and customer's satisfaction have an important role between the relationship of customer's experience and customer's loyalty, the mediating role of perceived value and customer's satisfaction is found to be full mediation

\section{Research Limitation and Future Research}

The main finding on the research is a new construct for experience quality variables, but the construct is built based on Malang City's traditional market. The future research should try to expand the scope of study by adding more traditional market from other city in Indonesia. The research is fall short from the number of variables which made the results are very limited, therefore we suggest future research could add more variables to the model to improve the accuracy and robustness of the construct model.

\section{Contribution to the Government and Society}

We highly recommend the government to improve the facilities of traditional market in order to compete better with department store. One of the facilities that is considered need to be improved is the facilities that support the interaction between the retailers and the customers. We suggest to giving more space between each kiosk so the customer could interact better with the retailer, in addition we highly recommend to separate the market into several department such as groceries, fashion store, and domestics's goods in order to keep the market tidy and clean. 
To the retailers we highly recommend to improve the layout of your kiosk, so you could interact better with your customers. We suggest retailers to start having a specific product so they could be placed in the department suited to their product. This way, customers would have no problem searching your products and you could have a loyal customer if you giving them a good service.

\section{REFERENCES}

Ars. 2015. The Role of Traditional Market as a foundation of "People Economy". http://www.dpd.go.id/artikel-957-peran-pasar-tradisional-sebagai-pondasidasar-ekonomi-kerakyatan viewed on March 2017.

Arianty, Nel. 2013. Analysis of The Differences Between Modern and Traditional Market According to The Lay Out and Service Quality in Order to Raise the Bargaining Power of Traditional Market. Jurnal Manajemen dan Bisnis Vol. 13 Nomor 01 April 2013.

Basic Needs Monitoring System. 2016. Empowerment Management. https://ews.kemendag.go.id/revitalisasi/pemberdayaan.aspx, accessed on March 2017.

Bilgihan, A., Madanoglu, M., \& Ricci, P. (2016). Service attributes as drivers of behavioral loyalty in casinos: The mediating effect of attitudinal loyalty. Journal of Retailing and Consumer Services, 31, 14-21.

Brady, M. K., \& Cronin Jr, J. J. (2001). Some new thoughts on conceptualizing perceived service quality: a hierarchical approach. Journal of marketing, 65(3), 34-49.

Brady, M. K., \& Cronin Jr, J. J. (2001). Some new thoughts on conceptualizing perceived service quality: a hierarchical approach. Journal of marketing, 65(3), 34-49.

Buchory, H. A., \& Saladin, D. (2010). Manajemen Pemasaran. Bandung: Linda Karya.

Chen, C.-F., \& Chen, F.-S. (2010). Experience quality, perceived value, satisfaction and behavioral intentions for heritage tourists. Tourism management, 31(1), 29-35.

Clemes, M. D., Gan, C., \& Ren, M. (2011). Synthesizing the effects of service quality, value, and customer satisfaction on behavioral intentions in the motel industry: An empirical analysis. Journal of Hospitality \& Tourism Research, 35(4), 530568. 
Clemes, M. D., Shu, X., \& Gan, C. (2014). Mobile communications: a comprehensive hierarchical modelling approach. Asia Pacific Journal of Marketing and Logistics, 26(1), 114-146. http://dx.doi.org/10.1108/APJML-04-2013-0040

Dick, A. S., \& Basu, K. (1994). Customer loyalty: toward an integrated conceptual framework. Journal of the academy of marketing science, 22(2), 99-113.

Dodds, W. B., Monroe, K. B., \& Grewal, D. (1991). Effects of price, brand, and store information on buyers' product evaluations. Journal of Marketing research, 307319.

Griffin, J., \& Herres, R. T. (2002). Customer loyalty: How to earn it, how to keep it: Jossey-Bass San Francisco, CA.

Hapsari, R., Clemes, M. D., \& Dean, D. (2017). The impact of service quality and customer engagement and selected marketing constructs on airline passenger loyalty. International Journal of Quality and Service Sciences, 9(1).

Hussein, A. S., \& Hapsari, R. (2014). How quality, value and satisfaction create passenger loyalty: An empirical study on Indonesia bus rapid transit passenger. The International Journal of Accounting and Business Society, 22(2), 95-115.

Indonesian President Regulation No. 112 Year 2007. The Regulation and Development of Traditional Market, Shopping Center, and Modern Shop. Chapter I: General Requirement. Clause 1: The Definition of Traditional Market.

Jacoby, J., \& Kyner, D. B. (1973). Brand loyalty vs. repeat purchasing behavior. Journal of Marketing research, 1-9.

Kotler, P., \& Armstrong, G. (2010). Principles of marketing: Pearson education.

Kuncahwati, H. 2016. Empowerment The Traditional Market and Their Seller According to The Regional Regulation of Purworejo Regency No. 6 Year 2014 (Case of Krendetan Market). http://repository.umy.ac.id/bitstream/handle/123456789/7548/JURNAL.pdf?seq uence $=1 \&$ is Allowed $=y$

Kuncahyo, Wahyu Sabda (2016). This Year Goverment Revitalizes 85 Traditional Market.http://ekbis.rmol.co/read/2016/02/28/237497/Tahun-Ini-PemerintahRevitalisasi-85-Pasar-Tradisional- accessed on March 2017 
Masitoh, E., A., 2013, Keeping Traditional Market Exist, Jurnal PMI, Vol. 10., No.2

Ministry of Trade. 2017. President Jokowi Wishes Traditional Market to Be More CompetitiveWithSupermarket.

http://www.kemendagri.go.id/news/2017/01/30/presiden-jokowi-ingin-pasartradisional-tak-kalah-dengan-mal accessed on March 2017.

Promono, A.H., A. Santoso, dan P. Indroyono. 2011. Menahan Serbuan Pasar Modern: Strategi Perlindungan dan Pengembangan Pasar Tradisional. Edisi Pertama. Cetakan Pertama. LOS-DIY (Lembaga Ombudsman Swasta-DIY). Yogyakarta

Reichheld, F. F. (1992). Loyalty-based management. Harvard business review, 71(2), 6473.

Ren, L., Qiu, H., Wang, P., \& Lin, P. M. (2016). Exploring customer experience with budget hotels: Dimensionality and satisfaction. International Journal of Hospitality Management, 52, 13-23.

Sekaran, U., 2000. Research Methods for Business; A skill business approach. New York: JohnWiley and Sons.

Sekarsari, L. A., Rohman, F., \& Hussein, A. S. (2016). Pengaruh Dining Experience Terhadap Customer Satisfaction, Restaurant Image, dan Behavioral Intention pada Casual Dining Restaurant di Kota Malang. Ekonomi Bisnis, 21(1).

Suhartanto, D., Clemes, M., \& Dean, D. (2013). Analyzing the complex and dynamic nature of brand loyalty in the hotel industry. Tourism Review International, 17(1), 47-61.

Tilaria Padika, 2016. Hari Pasar Rakyat Mengapa Harus Repot, tersedia online pada http://www.kompasiana.com/tilariapadika/hari-pasar-rakyat-mengapa-harusrepot_586902f2b29273d407006a41, diakses pada Maret 2017

Tu, Y.-T., Li, M.-L., \& Chih, H.-C. (2013). An empirical study of corporate brand image, customer perceived value and satisfaction on loyalty in shoe industry. Journal of Economics and Behavioral Studies, 5(7), 469.

Utomo, T.J. (2011). The Retailing Business Competition: Traditional vs Modern. Fokus Ekonomi, 6(1). 
Verhoef, P. C., Lemon, K. N., Parasuraman, A., Roggeveen, A., Tsiros, M., \& Schlesinger, L. A. (2009). Customer experience creation: Determinants, dynamics and management strategies. Journal of retailing, 85(1), 31-41.

Wu, H.-C., \& Li, T. (2014). A study of experiential quality, perceived value, heritage image, experiential satisfaction, and behavioral intentions for heritage tourists. Journal of Hospitality \& Tourism Research, 1096348014525638.

Wu, H.-C., \& Wu, H.-C. (2017). What drives experiential loyalty? A case study of Starbucks coffee chain in Taiwan. British Food Journal, 119(3), 468-496.

Wu, H.-C., Li, T., \& Li, M.-Y. (2016). A study of behavioral intentions, patient satisfaction, perceived value, patient trust and experiential quality for medical tourists. Journal of Quality Assurance in Hospitality \& Tourism, 17(2), 114-150.

Zeithaml, V. A. (1988). Consumer perceptions of price, quality, and value: a means-end model and synthesis of evidence. The Journal of marketing, 2-22.

Zeithaml, V. A., Bitner, M. J., \& Gremier, D. (2009). Services Marketing. 5th (edn): McGraw-Hill: NY.

Zeithaml, V. A., Bitner, M. J., \& Gremler, D. D. (2006). Services marketing: Integrating customer focus across the firm. 